\title{
K. MATSUOKA, M.D.: THE EXPERIMENTAL STUDY ON THE ENERGY OF THE ELECTRICAL COCHLEAR MICROPHONICS
}

\section{蝸牛電氣反應のエネルギーに關する㸴宽（第 2 編）}

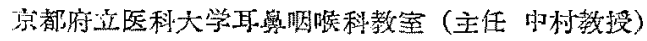

医学士 松阔擎焂

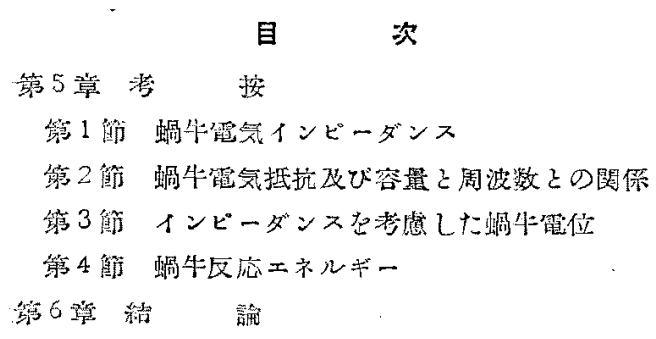

\section{第 5 章 考按}

第 1 節 蝸牛電気インピーダンス

生体組織のインピーダンスに関しては Einthoven

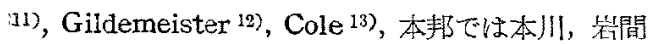
14)等の研究者が水イートストン橋或はコンウラ, シュ橋の平衡条件を利用してその湘定を行つた䛨細 な研究がある. 即ち橋の一つの腕に生体を，もろ一 つの腕に蓄䉓器と抵抗を，そして他の二つの腕に抵 抗をつなぎ，これに任意の周波数の正弦波交流を通 電し，適当な示雾器によつて電流の最小值き決定す るのである、斯くして测定された種々の生佮組織の 抵抗，容量及びインピーダンスは周波数の增加之共 に次第に減少し，無限大に於て抵抗山遂に一定值に 近付くので少る，この㥛限の抵抗值を $\mathrm{R}_{x}$ で婊わ すとすればこれは大体死組織の抵抗㽬に等しく，彼 等はこれを組織の真の抵抗 wahrer Widerstand と呼九でいる.そして生きた組織の抵抗 $\mathrm{R}$ 正稆限 の抵抗 $\mathrm{R}_{\infty}$ との差は生きた部分，即方細胞膜の抵 抗とみなして差支充ないであるうと指摘している。

そして細胞膜の分極容量をCとした脚致をの位 相角の正甽りアタタンス分と抵抗分の比で与兄ら れるから

$$
\tan \phi=-\frac{-\frac{1}{2 \pi \mathrm{fC}}}{\mathrm{R}-\mathrm{R}_{\infty}}=\frac{-1}{2 \pi \mathrm{f}\left(\mathrm{R}-\mathrm{R}_{\infty}\right) \mathrm{C}}
$$

$\phi=\tan ^{-1} \frac{-1}{2 \pi \mathrm{f}\left(\mathrm{R}-\mathbf{R}_{-c}\right) \mathrm{C}}$ は細胞膜の位相角と考兄 られ，最初 Gildemeister ${ }^{129}$ は㨁列等洒回路を”採 用して，璉ミの周波数の正弦波交流を生体組織炡

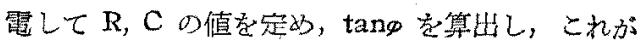
周波数によらず常に一定であることを発見しれ。併

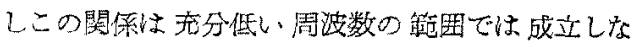
い. 即出抵抗を横軸化，リアクタンスを縦軸化とつ て，所謂周波数インビーダンス軌跡を画くと周波数 の充分に高い部分では直線を得るが，全周波数領域 に亘つて謂べると円弧になる。この事を明らかにし たのは Cole ${ }^{13)}$ であるが，彼は更に並列等価回路 を採用乙て筋, 神経, 晘臟等の生体租織の $\mathrm{R}, \mathrm{C}$ を 算出し，それによつて得られた位相金は全周波数領 域に宣つて一定ですること発確めた。

䪪通の生体組織では位相角は大体 $45^{\circ}$ 上 $90^{\circ}$ の中 間の值が皇られている。例点ば牛の血液 $49^{\circ}$, 蛙の

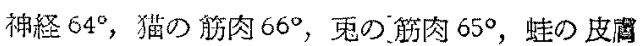
$66^{\circ}, 76.5^{\circ}, 84^{\circ}$ ，人間の皮葴 $64^{\circ}, 72^{\circ}, 75^{\circ}, 77^{\circ}$ 等 である。

以上述べた研究はすべて発振器より発生させた正

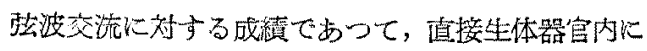
発生した脈流比対する成績ではない，生体器官内に 発生する眽流の波抢は一般に複雜で不規則なものが 多く，又任意の周波数の正弦波を得ることは出来な いのであるから，死家利用して通接その生体器官の インビーダンスを測定することは不可能汇近い，搠

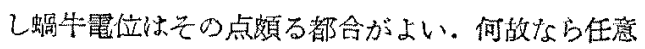
の周洨数の純音 (正弦波) に対して忠策に波形の転 輍を行い得るからである。

斯くして螖牛内に発生した種々の周波数の振動電 流に対する螖牛の抵抗，容量及びインピーダンスる $7-10$ 
前編実成験贖の章で述ベた通り，やはり周波数の兽

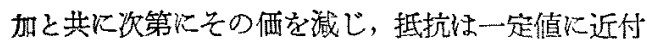
く傾向を示している。

佮蛤牛の周波数インビーダンス軌跡老兒てみると 私の垁験成續からだけでは直列等倠回路を採用した 場合には軌跡は门胍になり，並列等俩回路を採用し た場合に性全閣波数領域に亘り，位相角一定の法則 があてはまるだろうという推定を下すことは出来な いが，充分周波数が高い籍囲内では軌跡は固線とな り特に並列等価回路を採用した場合はその傾问が著 明である，征つて周波数が先分高い領域では位相有 一定の法則があてはまる結果になる。本奏験の結果 ではこの位相解は大体 $57^{\circ}$ と $65^{\circ}$ の間の值が得られ ている。

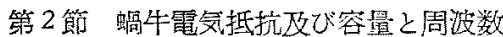 之心哭係}

生体組鐡の抵抗及び容量は金属等の純粋の物理的 抵抗及び容量と法全然異なつて周波数によつて变化 することは前編に揭げた第 5 图より第8图迄の片対 数座標上のグラフからる明らかであるが，この䦐係 を更に明らかにするために雨対数座標上の教軸に周

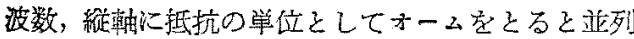
等価回路で算出した抵抗更びリアタタンスは第 13

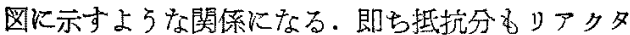

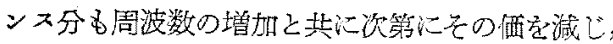
その傾向は再刘数座標上では大体直線的であること が半る.

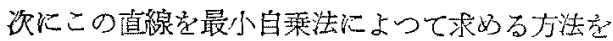
考之てみる ${ }^{15}$ ，先す抵抗分の直線を求めることに

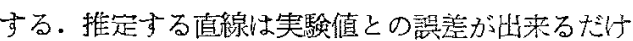

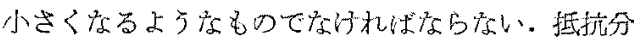
の笑験值を $\mathrm{R}$ とし，それに対する推定傎を $\mathbf{R}^{\prime}$ と すれば，推定の愦美はこの場合 $\left(\log \mathrm{R}-\log \mathrm{R}^{\prime}\right) て$ 与えられる。このるうな誤差性正負の值ととり得る から，その和はうまくあてはまつていないような直 線に対してるいくらでる小さくなり得る。徉つて䉓 にそのよう文誤差の和觉出来るだけ小さくなるよう に要求するだけでは䭾目である。この難点は誤䛵の 絶対值の和出来るだけ小さく要求りることによつ

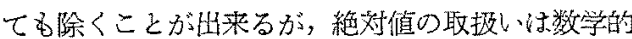
には便和でないから愦差の自乗の和を最小にするる

う要求するのがよいことになる。

$200 \mathrm{cps} よ り 10000 \mathrm{cps}$ 类ての 11 個の点に対して

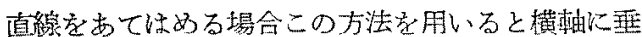

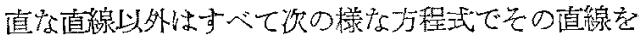
表すこと方泏来る。

$$
\log R^{\prime}=-m \log f+n
$$

但し， $\mathrm{f}$ は周波数， m, n は正の常数とする。

即方上記の問題性推定誤羑 の兒乗の和が最小になるよ に $\mathrm{m}$ と $\mathrm{n}$ の值尊定方間 題になる。言美の自乘の和る $\sum\left(\log \mathrm{R}-\log \mathrm{R}^{\prime}\right)^{2}$ となるわ $ら \log \mathrm{R}^{\prime}$ の代りに(21) の

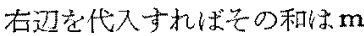

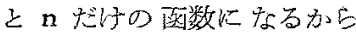

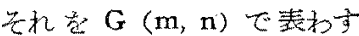
ことに光。。

$G(m, n):=\sum(\log$

$\mathrm{R}+\mathrm{m} \log \mathbf{f}-\mathrm{n})^{2} \cdots(22)$ この四数が最小炕なるたるに

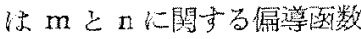
が其に雾になることが必要じ 䗆。即吉 
$\frac{\partial G}{\partial m}=\sum 2(\log R+m \log f-n)(\log f)=0 \cdots$

$\frac{\partial \mathrm{G}}{\partial \mathrm{n}}=\Sigma 2(\log \mathrm{R}+\mathrm{m} \log \mathrm{f}-\mathrm{n})(-1)=0 \cdots(24)$

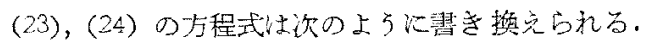
$-m \sum(\log f)^{\circ}+n \sum \log f=\sum \log R \log f \cdots(25)$

$-\mathrm{m} \sum \log \mathrm{f}+\sum \mathrm{n}=\sum \log \mathrm{R}$

この場台 $\sum \mathrm{n}=11 \mathrm{n}$ となるから (25)：(26）の屰立 方程式を $\mathrm{m}, \mathrm{n}$ に就て解けば

$$
\begin{aligned}
& \mathrm{m}=\frac{11 \sum \log \mathrm{R} \log f-\sum \log \mathrm{R} \sum \log f}{\left(\sum \log f\right)^{2}-11 \sum(\log \mathrm{f})^{2}} \ldots \ldots \ldots . . \\
& \mathrm{n}=\frac{\sum \log \mathrm{R} \log f \sum \log f-\sum \log \mathrm{R} \sum(\log f)^{2}}{\left(\sum \log f\right)^{2}-11 \sum(\log f)^{2}} .
\end{aligned}
$$

従つて (27)，(28) の有辺の $\mathrm{R}$ に実験值， $\mathrm{f}$ に周 波数を代人すれば $\mathrm{m}, \mathrm{n}$ の值が求められる。

こ我を実際汇求めてみると $\mathbf{m} \div 0.711, \mathbf{n} \doteqdot 4.809$

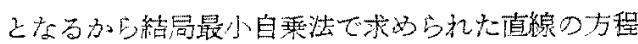
式は次の上万書くことが出莱る。

$$
\begin{gathered}
\log R^{\prime}=-0.711 \log f+4.809 \\
\mathbf{R}^{\prime}=10^{4.859} \mathbf{f}^{-3.717} \\
\mathbf{R}^{\prime}=6.442 \cdot 1 \mathbf{H}^{-1}-0.717 \ldots .
\end{gathered}
$$

リアタタンス分 X の挰式も同様にして求るる ことが出来る。

$$
\mathrm{X}^{\prime}=8.110 \cdot 10^{4 \mathrm{f}^{-2}-655}
$$

又 $\mathrm{X}=1 / 2 \pi \mathrm{fC}$ なる関倸より容量 $\mathrm{C}$ の方程式は 次のよ5になる。

$$
\mathrm{C}^{\prime}=1.963 \cdot 10^{-6} \mathrm{f}^{-0.345}
$$

先にむ迹べた通り生体組織の分極作用は签量とし て働き，䉓流，電压間の位相差の原因となる。併し 分極容量や生体組織の抵抗は純粋な物理柔の容量や 抵抗のように一定でなく周波数の指数政数であるこ 々は (29)，(31)・の求によのても眀らかである。

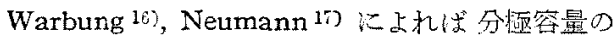
中でイオンの脑散による部分注可道電㥛に於ては周 波数の平方根に反比例し，イオンの電気的二重管に

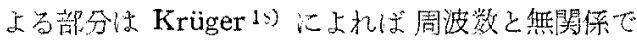
苏ると云わ礼ている。

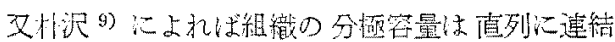
されな電気的二重曾容量部分と拉散容量部分と上り

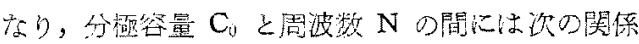
污成立等ると云う。

$$
\frac{1}{\mathrm{C}}=\alpha+\beta \vee \mathrm{N}
$$

但し $\alpha, \beta$ は常数である。

併しこの関係は朴沢の実娩によれば $1000 \mathrm{cps}$ 以 上の周波数に対してのみ満足にあては主り，低い周 波数領域に対しては一定の偏差を示すことが明らか にされた。彼は最初低い周波数領域には不適当な直 列等洒回路を採用したつめ，この偏羑を生じたので あ万らと考市たが，並列等価回路を用いてもやはり 低周波領域に於ては一定の偏差を示すことを認め た。そこで各仾究者は種々な並列等価回路模型を考 えてその政善它試みたが結局見るべき結果は得られ なかつた。

その後本川，岩閒19》は Frick 20)の 分極容量を 周波数の指数函数で表方した次の式を採用すること によつてこの問題を解決した。即ち

$$
\mathrm{C}=\mu \mathrm{N}^{-v}
$$

但し $\mu$ 及び V は正の常数である。

そして上式の V に1/2を代入したときは先に述 ベた理論的な㹡散容量部分に一致し，V演を代入 したときには電気的二重畨容量部分に一致する。又 リアクタンスX X $1 / 2 \pi N C$ 《等しい関係より上 式上り更に次の式を誘導している。

$$
\mathrm{X}=\mathrm{bN}^{-1}
$$

そして $\mathrm{R} / \mathrm{X}$ は一定である関係より

$$
R=b^{\prime} N^{-3}
$$

但し $\mathrm{a}, \mathrm{b}$ 及び $\mathrm{b}^{\prime}$ 注常数である。

本川，岩間はこの式を採用して，実験結果方全周 波数領域に亘り满足にあては安ることを磪めた。

文Frick は位相角 $\phi$ 指数 a 間に $\phi=\frac{\mathrm{a}}{2} \pi な$

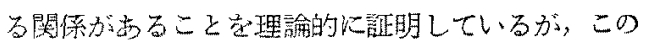
関保も本川，岩間は実験的にも成立することを確認 している.

さて私が笑験成續より最小自乘法で求めた(29)， (30) 及び (31) の式も大体 Frick の式に一致して いる. $\phi=\frac{\mathrm{a}}{2} \pi$ の に(29), (30) 式の周波数の指 数を代入して $\oplus$ 求めて欢ると（29）式上り 1.117 radian, (30) 式より $\phi=1.029$ radian とな る.これ等の洒注前節で述べた位相角之略よ一致し ている.

第3節 インピーダンスを考慮した蝸牛電位 㽍牛電位の根源はコルチ哭官，特儿毛細胞であ 
るとする Wever, Davis, Derbyshire, Lurie, Saul 4) 等の所謂毛細胞説て従えば，毛細胞を一椣の 生体発電器と䓔光ることが出来, 基底膜上には之等 の多くの発電器が規則正しく配置されていると考兄 て差支充ない，乙して刺战音の音生攻び周波数に刘 する真の螖牛電位の大いさ活動発電器の数及び夫 夫の発電器的起電力によって決定される。従つて塞

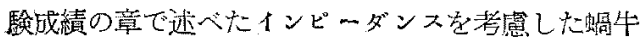
電位即ち真の蝸牛電位は個ふの発電器に生ずる起電 力の和と考えてよい，従つて若し同一音圧に対する 棝々の毛細胞の否電位特性が全基底膜に亘り皆等し いと仮定するならば本実験の絬果は低音は同じ音王 の高音よりも多数の毛細胞を剌戙するものであるこ とを示している.そこで今毛紐胞とい5名の発電器 が基底膜の全長酒つて面列に䕗結されているとみ なすならば，真の蝸牛電位の大いさ注基底膜の振動 籍囲に支配されることになり，実験結果上り低音域 に対する基底膜の振歌範围は広く，従つて又气の振 動振幅も大であり，高音域に移るに従つて振動籍团 は次第に狭くなり一椆所潗中される傾向のあるこ

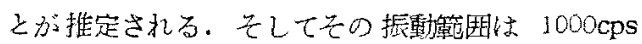
以上の高音域では急激に減少することを示してい

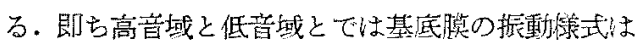
全く対称的なものであろうと想像される。

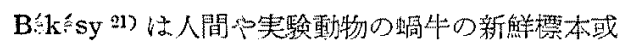
は固定標本で基底膜の振動状態をストロボスロープ

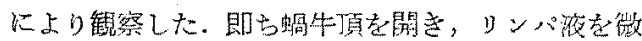


の後純音刺战に上るこれ等微粒子の振動状態学篗察 した. 其の結果より $200 \mathrm{cps}$ の純音に対しては基底 膜は殆ど全長に亘り振動し，600 cps に对しては少 くとも其の $2 / 3$ の長导に亘り振動が見ら机るといら 結果莨出している。

又 Wegel, Lane 2 2) ( 遮濑曲線より 基底营の振

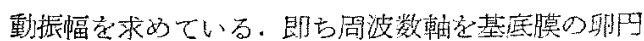



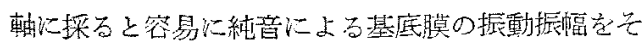
の全長汇亘つて求るることが出るとい5のであ る。この力法によつて彼等㛎各周波数に就て基底膜

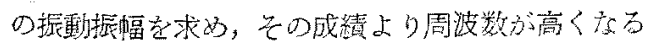

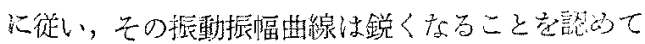

いる.

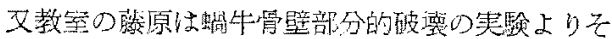
の寻所損賃俚高音に於て蝸牛電位の著明な低下を米

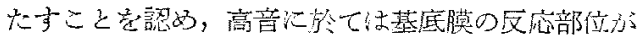
比較的限局されるという結諭を出している。

悡の箺験成禎も大体こ扎らの笑験結果と上く一致 している.

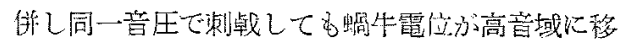
るに従って急激に減少するということは或虹細胞膜

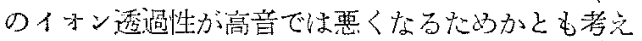
ら水る。

第 4 節 蛤牛反応ェネルギー

Tröger 23) 等は人間の中耳の音響・ンピーダンス を测定した結果, 大体 $800 \mathrm{cps}$ 前後で驾突のイン ピーダンス $\rho \mathrm{C}=42$ に略等しくなり impedance matching が行わ机る之云っている. 梴つて同じ音 压で刺㥂した場合には $800 \mathrm{cps}$ 前後のとき毛細胞に 到達する音裂エネルギーは最大となると考えられる が，私の実戨の結果では発生する電文卡ルギーは $500 \mathrm{cps}$ 前後に桨が見られ，そ机より高音域では急 激红減少与るが低音域では娍少が少ない、結果になつ ている。このずれは或いは伝音系の transmission



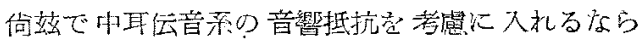

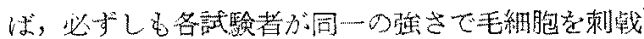
しているとは云定ない，即方 10000ps 以下の低音 域では俱膜面で反射される量が大であるから低音は

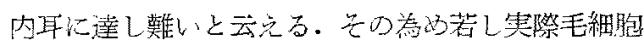
を刺㦸する音の強さを同一にするならは面低低音域

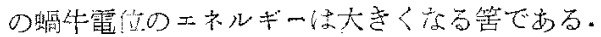

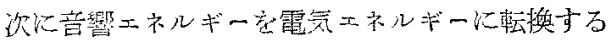


牛電位の上万な䉓気エホルギーに变る点には異諭は

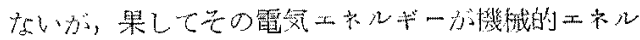
ギーより供給さ㧈ているかざらか记就ては二のの見

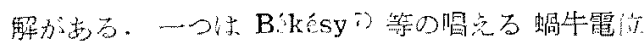
のェホルギーは侳体ェネルギーより供給されてい て，毛稩胞で亦ルギーの增加方行放れると云了択

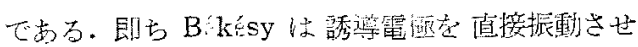
て，こ机で少数の毛細胞壱刺戟与ると共にその電位

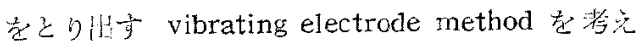


た・そしてこの雪㥛で毛緗胞の毛学螖牛の軸儿対乙 radial の方向炕動かした時蜩牛電位は最も大きく， 且つ歪主した恋位に相当した電位が現れ，その電位 は決して毛の運動の速度によらないことを見出し た。更に彼は電極の先端に加わる力を直接测定泊来

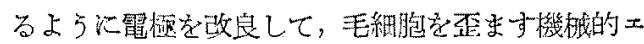
ホルギーを测ると共に，Apex の外リンパとVestibulum の外ワンパとの閒の直流雵位の增加量とを 比較して正常条件下の動物では刺战として加党号孔 た機械的エネルギーよりは蜩牛队消费される䉓気 ェネルギーのうが大であることを見出し，蜩斗䉓位

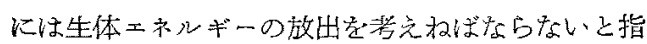
摘している。これれ対して de Vries ${ }^{8)}$ 等は魚の側 線で行つた奏験より，感覚細胞に加无た機栰的エネ ルギーの斿生ずる電気エネルギー上り大であると 云い，エネルギーの增加屉至放出否定している。

そこでいま Békésy 等の唱劣る説に従党ば毛細 盷に到達した音響ェネルギーは私の寒験成績より小 さくなければならないし，反対に de Vries 等の説

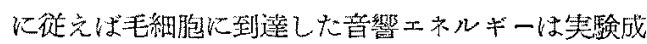
䥊より大きくはなり得ても小さくはなり得ない䇢て

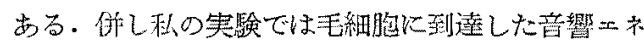
ルギー路测定主ることは出来ないので，試験耳上K 吊したマイクロフォンの位置での 音響メネルギーと 比輍することにした。

そこで音響ェネルギーが問題になつて来るが，音


当:4).

$$
\mathrm{I}=\frac{\mathrm{P}^{2}}{\rho \mathrm{C}}
$$

茲に P は压力の実効值, $p$ 法媒質の密度, C は音 の速度である.依つて若しPをbar (dyne $/ \mathrm{cm}^{\mathrm{g}}$ ) で表し，Cを $\mathrm{cm} / \mathrm{sec}, \rho$ を/ $/ \mathrm{cc}$ で菱せば，Iは $\mathrm{erg} / \mathrm{sec} / \mathrm{cm}^{2}$ で表される。然るに 10erg/ $\mathrm{sec} か$ $1 \mu \mathrm{W}$ 飞相当するから

$$
\mathrm{I}=\frac{1}{10} \frac{\mathrm{P}^{2}}{\rho \mathrm{C}} \mu \mathrm{W} / \mathrm{cm}^{2}
$$

となる。

$20^{\circ} \mathrm{C}$ 淤厂 $\rho=0.001205, \mathrm{C}=33150+61 \times 20=$

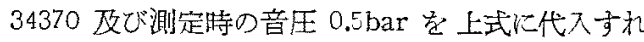
ば

$$
\mathrm{I}=0.0024 \times 0.5^{2} \mu \mathrm{W} / \mathrm{cm}^{2}=6 \times 10^{-4} \mu \mathrm{W} / \mathrm{cm}^{2}
$$
そこで今笑験動物の 鼓躇の面積を $0.25 \mathrm{~cm}^{2}$ と仮定 するならば，豐膜が摄受する音響エネルギーは大約 $15 \times 10^{-5} \mu \mathrm{W}$ となる. 又丰細胞に発生する電気ェネ ルギーは先に述べたように $500 \mathrm{cps}$ 前後が最大で， その婸合值性 $1.4 \times 10^{--5} \mu \mathrm{W}$ となるがら，鼓膜に到 详した音響エネルギーの略1/10が電気エネルギー 飞䎐換され，爾余虻鼓膜より毛細胞をでの径路で消 損されることになる，そして500eps 上り低音域或


士る。

併し篹験結果のェネルギーの值は採用した並列等

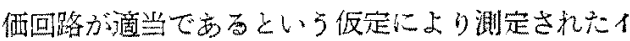
ンビーダンスの量からェネルギーを算出したるので あつて，䇛際の蝸牛の電気模型恃更に複雜であり，

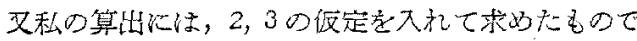
あるから或程度の誤差が入っているものと考克なけ 机ば方らない。

\section{第 6 章 結 論}

蛣牛反応のエネルギーの問題は最近やがしく取 り上げられて来たが，未だ未解決原点が頗る多い。

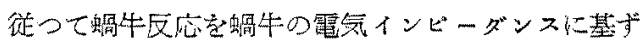
いて量的に测定したといら研究も未だ発表されてい ない状態である。皮生体インビーダンスに開する研 究は誃数あるが，生体内心発生した脈流交利用して その測定を行つたといら研究も今の処未だ見当らな

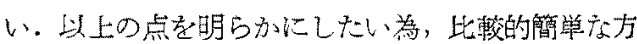
法で奏騃を企図し，次の結果究得た。

1) 蝸牛の電気抵抗及び電気容量注周波数の指数 崡数で表少すことが出来，抵抗も容量も共に周波数

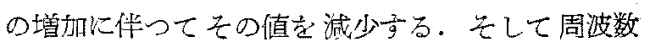
ダ充分に高い簵囲内では位相角一定の法則方成立 する。

2)インピーダンスを洘慮した䗁牛電位は一定音 生で刺㦸しても $1000 \mathrm{cps}$ より低音域で高音域儿 比較して蝸牛電㕸は遥か心大き!。

3）蛤牛区応の䉓気エホルギーは一定音圧で刺㦸 乙た埸合 $500 \mathrm{cps}$ で極大を示し，高音域では急激に

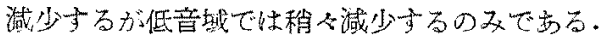

4）内耳に発毛した電気エホルギーは鼓膜に到啥 した音響エネルギーの大約1/10である。 


\section{主 要 交 嗝}

1) Forbes. A., Miller. R. H. and O. Conntor: Amer. J. Physiol. 1927. 80, 36. 2) Wever, E. G. \& Bray. C. W.: J. Expr. Psychol 1936, 19, 129. 3) Adrian. E. D.: J. Physiol. 1931, 71, 28. 4) Davis. H. \& Derbyshire, A. J.: Amer. J. Physiol. 1934, 107, 311. 5) Hallpike. C. S. \& Radon-Smith. A. F.: Annals Oto-RhinoLaryng. 1937, 46,976. 6) Davis, H. \& Tasaki, I. Science, 1952, 116, 519. 7) Békśsy, G.: J. Acous. Soc. Amer. 1951, 23, 29. 8) de Vries: J. Physiol. 1952, 116, 137. 9) 本川弘 $\rightarrow$ : 医学, 生物学電氮的実驗法, 南仙堂, 1950: 笔気生理学，岩波畫店，1952.10) 本川弘一： 絲波，南条畫店，1950，11）Einthoven，W.\& Bijtel, J.: Pfüger's Arch. 1923, 198, 464. 12) Gildemeister, M.: Pflüger's Arch.: 1928, 219 , 89. 13) Cole, K. S.: J. Gen. Physiol. 1932, 15, 641; Spring Harb. Symp. 1933, 1, 107. 14) Motokawa \& Iwama: Tohoku J. Eqper. Med. 1947, 49, 89. 15) Hoel, P. G.: Introduction to Mathematical Statistics 1947 . 16) Warb- urg, E.: Ann. Phys. Chem.: 1899, 67, 494. 17) Neumann, E.: Ann. Phys. Chem. 1899, 67, 500. 18) Krïger, F.: Zeitschr. f. Phys. Chem. 1903, 45, 1. 19) Hozawa, S.* Plüger's Arch. 1931, 92, 209.; J. Biophys 1925, 1, 185. Zeitschr. f. Biol. 1931, 91. 297. 20) Frick, H.: Phil. Mag. 1932, 14, 310. 21) Bekbsy, G.: J. Acoust. Soc. Amer. 1949, 21, 245. 22) Wegel \& Lane: Phy. Rev. 1924. 23) Tröger: Phys. Zeitschr.

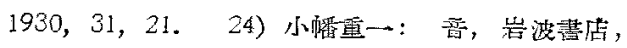
1952.

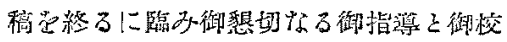

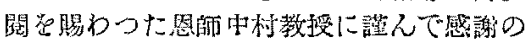

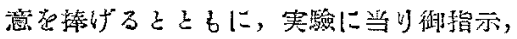

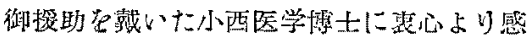
謝する。

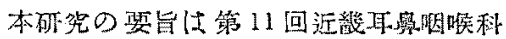
学会, 第 54 回日本耳學咽喉科学会総会乙

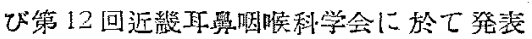
しだ.

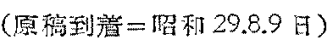

H. SENGOKU, M.D.: EXTERNAL NOSE AND NASAL AIR CURRENT

\section{外鼻々腔所見飞鼻內氮流に就て}

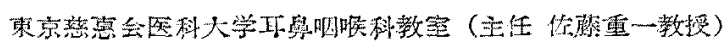

$$
\text { 副手仙 石熦 }
$$

\section{緒霉}

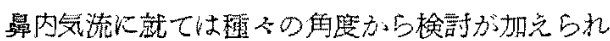

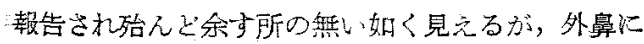

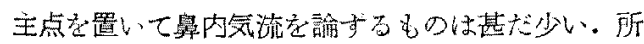

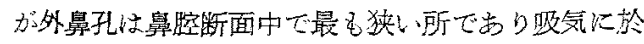

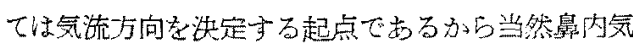
流上飞重要な意味を持つ篦てめる。倘人類の外鼻は 動物の夫れと較ぐて極好異なつた特異な形態を持

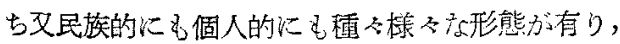

$7-15$
之等がそれそれれ鼻内気流の観点から如何なる機能的



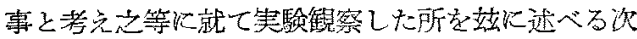
第である。

$$
\text { 方法 }
$$

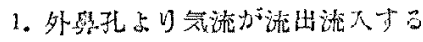
状態の短察

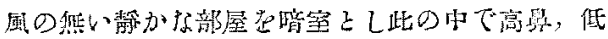

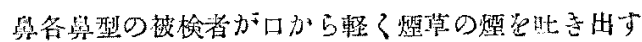

